\title{
PENATAAN BATAS WILAYAH ADMINISTRASI DESA, HAMBATAN DAN ALTERNATIF SOLUSI DENGAN PENDEKATAN GEOSPASIAL
}

\section{ARRANGEMENT BORDERS ADMINISTRATION VILLAGE, BARRIERS ANDALTERNATIVE SOLUTIONS WITH GEOSPATIAL APPROACH}

\author{
Asadi \\ Balai Diklat Geospasial-Badan Informasi Geospasial (BIG) \\ Jl. Raya Jakarta Bogor KM.46 Cibinong 16911 \\ Telp.:+62218754601, Faks.:+62218763856, hp:+628128616750 \\ Anggota Penyusun Permendagri No.27/2006 tentang Penetapan dan Penegasan \\ Batas Desa \\ E-mail: asadi.ibr@gmail.com
}

Naskah diterima: 14 Maret 2016, revisi pertama: 13 Mei 2016, revisi kedua: 9 Juni 2016

\begin{abstract}
Law No. 6 of 2014 concerning Villages provides additional evidence that Indonesia has paid more attention and respect to the existence of villages. The significant amount of village expansion lately is not matched with the clarity of village boundaries that may rise in to potential conflicts. Ideally, the entire instruments to structure village boundaries must first be prepared. One of the instruments needed is the availability of large scale of basic maps (topographical maps) as the main instrument of making a village map. Unfortunately, the large-scale topographical maps are not available yet. This paper provides an alternative acceleration of village boundaries arrangement using High Resolution Satellite Imagery Data that has passed orthorectified process. By involving the community and village leaders in the process of structuring boundaries, and supported by the spirit of fraternity, all problems occured during the activity of village boundaries can be solved with the very best solution.
\end{abstract}

Keywords: village boundary, High Resolution Satellite Imagery Data, spirit of fraternity

\begin{abstract}
Abstrak
Undang-Undang Nomor 6 Tahun 2014 tentang Desa memberikan tambahan bukti bahwa negara semakin memperhatikan dan menghormati keberadaan desa. Adanya pemekaran wilayah desa yang signifikan akhir-akhir ini, tidak diimbangi dengan kejelasan batas wilayah desa,berpotensi menimbulkan konflik. Idealnya, seluruh instrumen
\end{abstract}


untuk melakukan penataan batas wilayah desa harus terlebih dahulu disiapkan. Salah satu instrumen tersebut adalah tersedianya peta dasar (peta rupabumi) skala besar sebagai bahan utama pembuatan peta desa. Sayangnya ketersediaan peta rupabumi skala besar belum tersedia. Tulisan ini memberikan alternatif percepatan penataan batas wilayah desa yang dapat menggunakan Citra Satelit Resolusi Tinggi (CSRT) yang sudah melalui proses ortorektifikasi. Dengan melibatkan masyarakat dan tokoh masyarakat desa dalam melakukan proses penataan batas wilayah, dan dengan didukung semangat persaudaraan, diharapkan permasalahan batas wilayah desa dapat diselesaikan dengan sebaik-baiknya.

Kata kunci: batas desa, metode kartometrik, CSRT, semangat persaudaraan

\section{A. PENDAHULUAN}

Mengutip dasar pemikiran pembentukan Undang-Undang (UU) Nomor 6 Tahun 2014 tentang Desa disebutkan bahwa desa atau yang disebut dengan nama lain telah ada sebelum Negara Kesatuan Republik Indonesia terbentuk. Sebagai bukti keberadaannya, terdapat dalam Penjelasan Pasal 18 Undang-Undang Dasar Tahun 1945 yang menyebutkan bahwa dalam teritori Negara Indonesia terdapat lebih kurang 250 "Zelfbesturende landschappen" dan "Volksgemeenschappen" seperti desa di Jawa dan Bali, nagari di Minangkabau, dusun dan marga di Palembang. Menurut Sujamto 1988, pengertian volksgemeenschappen yang berasal dari bahasa Belanda, adalah desa dan yang setingkat dengan itu. Atas dasar pemikiran tersebut, negara berkewajiban untuk memberikan perlindungan dan tetap melestrasikan keberadaannya sebagaimana penjelasan Pasal 18 UUD 1945 di atas. Jika kita melihat sejarah perundang-undangan yang mengatur keberadaan desa, di antaranya UU Nomor 19 Tahun 1965 tentang Desa Praja, UU Nomor 5 Tahun 1979 tentang Pemerintahan Desa, UU Nomor 22 Tahun 1999 yang secara eksplisit mengakui otonomi desa, maka sudah tidak diragukan lagi bahwa negara telah memberikan perlindungan dan tetap melestarikan keberadaan desa.

Terbitnya UU Nomor 6 Tahun 2014 menambah keyakinan kita bahwa negara sangat memperhatikan dan menghormati eksistensi desa. Hal ini tentunya didasarkan atas beberapa pertimbangan yang komprehensif terhadap perkembangan zaman, kebutuhan dan kepentingan masyarakat. Hingga April 2015, sudah ada 74.093 desa dan 8.412 kelurahan di seluruh Indonesia (Prasetyanto, 2015). Kenyataan ini mengindikasikan bahwa jumlah pemekaran wilayah desa telah terjadi begitu spektakuler. Menteri Keuangan, seperti dilaporkan republika.co.id pada edisi 10 Desember 2015, menghimbau Pemerintah Daerah untuk mengendalikan jumlah desa agar penyerapan dana desa lebih optimal.

Ditinjau dari aspek spasial kewilayahan, masih banyak wilayah desa yang belum mempunyai garis batas yang tegas dan mempunyai peta wilayah desa yang dibuat sesuai dengan kaidah-kaidah pemetaan. Kondisi ini tentu akan berakibat kepada belum jelasnya luas wilayah desa. Jika kita perhatikan Peraturan Pemerintah (PP) Nomor 60 Tahun 2014 tentang Dana Desa yang bersumber dari APBN menyebutkan bahwa pengalokasian dana untuk desa, salah satunya didasarkan pada luas wilayah desa. Disini terlihat bahwa luas wilayah dan tegasnya garis batas wilayah menjadi hal penting untuk segera diselesaikan. Disamping itu, akibat belum jelasnya garis batas wilayah antar desa akan menimbulkan persoalan besar dan berpotensi terjadinya konflik horizontal. 'Peta' wilayah desa yang terpampang di setiap kantor desa umumnya belum dibuat berdasarkan kaidah-kaidah pemetaan. Peta tersebut hanya sebatas 'sketsa' yang menggambarkan bentuk umum wilayah administrasi dari desa tersebut dan sudah barang tentu luas wilayahnya tidak bisa ditentukan berdasarkan 'peta' tersebut. 
Tulisan ini mencoba membahas aspek spasial penataan batas wilayah desa dan kendala yang saat ini terjadi serta alternatif penyelesaiannya.

\section{B. KERANGKA TEORI}

\section{Informasi Geospasial (IG)}

Sebelum membahas hal yang terkait dengan penataan batas wilayah, ada baiknya disampaikan terlebih dahulu pengertian umum tentang Informasi Geospasial dan bagaimana hubungannya dengan penataan batas wilayah administrasi. Undang-Undang Nomor 4 Tahun 2011 tentang Informasi Geospasial menyebutkan bahwa Informasi Geospasial adalah data geospasial yang sudah diolah sehingga dapat digunakan sebagai alat bantu dalam perumusan kebijakan, pengambilan keputusan, dan/atau pelaksanaan kegiatan yang berhubungan dengan ruang kebumian. Data geospasial adalah data tentang lokasi geografis, dimensi atau ukuran, dan/atau karakteristik objek alam dan/atau buatan manusia yang berada di bawah, pada, atau di atas permukaan bumi. Geospasial atau ruang kebumian adalah aspek keruangan yang menunjukkan lokasi, letak, dan posisi suatu objek atau kejadian yang berada di bawah, pada, atau di atas permukaan bumi yang dinyatakan dalam sistem koordinat tertentu.Merujuk kepada UU Nomor 4 Tahun 2011 tentang Informasi Geospasial, bahwa Informasi Geospasial terdiri atas Informasi Geospasial Dasar dan Informasi Geospasial Tematik. Informasi Geospasi Dasar (IGD) adalah Informasi Geospasial yang berisi tentang objek yang dapat dilihat secara langsung atau diukur dari kenampakan fisik di muka bumi dan yang tidak berubah dalam waktu yang relatif lama.

Gambar 1. memperlihatkan skema Informasi Geospasial Dasar. IGD ini meliputi Jaring Kontrol Geodesi dan Peta Dasar. Jaring Kontrol Geodesi (JKG) meliputi Jaring Kontrol Horizontal Nasional (JKHN), Jaring Kontrol Vertikal Nasional (JKVN) dan Jaring Kontrol Gayaberat Nasional (JKGN). Secara fisik di lapangan, JKG berupa tugu-tugu dengan ukuran tertentu yang tersebar dengan jarak tertentu di seluruh wilayah Indonesia. Tugu-tugu tersebut sudah mempunyai nilai koordinat, nilai ketinggian dan nilai gayaberat yang teliti.Nilai-nilai tersebut dijadikan acuan referensi untuk pengukuran posisi teliti, pengukuran tinggi teliti dan pengukuran gayaberat teliti. Peta Dasar berupa Peta Rupabumi Indonesia (RBI), Peta Lingkungan Pantai Indonesia (LPI) dan Peta Lingkungan Laut Nasional (LLN).

Sumber: BIG, 2012.

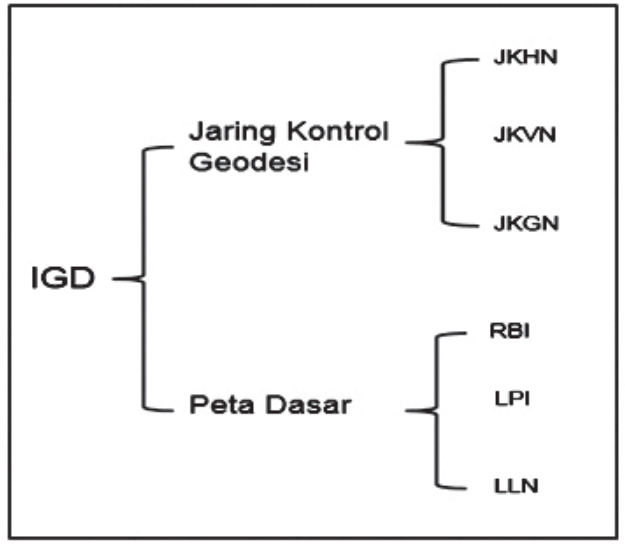

Gambar 1.

Skema Informasi Geospasial Dasar 
Dalam kaitan penataan batas wilayah, peta RBI memegang peranan yang sangat besar untuk dijadikan acuan dan sangat ditunggu keberadaannya secara lengkap untuk seluruh wilayah NKRI. Peta ini dibuat dalam berbagai skala, mulai skala kecil, sekala menengah sampai skala besar. Sayangnya keberadaan peta ini, baik ditinjau dari kelengkapan skala, maupun dari kelengkapan cakupan wilayah, masih dirasa belum lengkap.

Informasi Geospasial Tematik (IGT) adalah Informasi Geospasial yang menggambarkan satu atau lebih tema tertentu. Ada banyak contoh dari IGT, antara lain peta Kemiringan Lahan, peta Morfologi, dan peta-peta tematik bidang kehutanan, perkebunan, pertanian, pertanahan,sumberdaya mineral.

Apabila dikaitkan dengan penataan batas wilayah administrasi, ada peta wilayah provinsi, peta wilayah kabupaten, peta wilayah kota, peta wilayah kecamatan, peta wilayah desa dan peta wilayah kelurahan. Seluruh peta wilayah administrasi itu masuk dalam kategori Informasi Geospasial Tematik. Melihat pada cakupan area, wilayah administrasi provinsi secara umum lebih besar luasnya jika dibandingkan luas wilayah kabupaten/kota, demikian seterusnya, dan luas wilayah yang lebih kecil adalah wilayah desa/kelurahan.

Sesuai ketentuan UU Nomor 4 Tahun 2011, bahwa IGT harus merujuk kepada IGD, artinya sistem referensi koordinat yang diacu oleh setiap IGT harus satu sistem referensi dengan sistem referensi yang digunakan oleh IGD. Apabila di suatu daerah sudah tersedia peta RBI yang sesuai dengan kebutuhan, maka peta RBI tersebut harus digunakan sebagai bahan baku pembuatan peta tematik. Amanat UU ini salah satunya bertujuan untuk menghindari tumpang tindih yang selama ini sering terjadi.

\section{Bentuk Garis Batas Wilayah}

Jika berbicara secara umum tentang identitas batas wilayah administrasi, baik batas desa, kabupaten/kota maupun batas provinsi, setidaknya ada dua acuan yang sering digunakan. Acuan pertama adalah berupa objek alami, seperti sungai, punggung bukit. Acuan kedua adalah berupa objek buatan manusia, seperti jalan raya dan jalan kereta api. Untuk batas wilayah negara pun kedua objek tersebut juga digunakan. Seperti diketahui, garis batas wilayah merupakan garis khayal yang hanya tergambar di atas peta dengan menggunakan simbolsimbol tertentu dan garis khayal tersebut tidak ada di lapangan. Ada garis batas yang bukan hanya tergambar di atas peta, akan tetapi garis batas itu dibuat di lapangan dengan lebar koridor 20 feet dengan panjang ratusan mil seperti terlihat pada Gambar 2.Sayangnya garis batas semacam itu tidak ditemukan di wilayah Indonesia. 


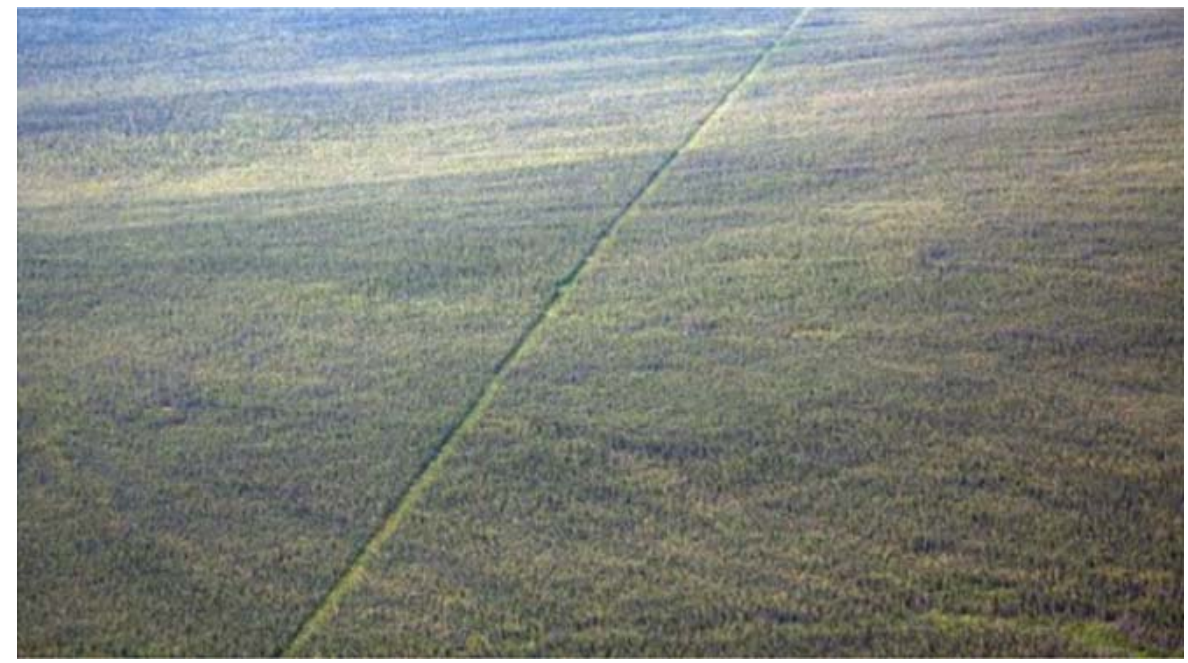

Sumber: Alaska Dispatch News, http://www.adn.com/article/July 27, 2014.

Gambar 2.

Garis batas negara USA (Alaska)-Canada membentang pada meridian $141^{\circ}$ Bujur Barat

Setiap peta RBI selalu memuat garis batas wilayah administrasi dalam bentuk simbol dan keberadaannya tergantung pada skala peta. Garis batas wilayah desa misalnya, hanya ada pada peta RBI skala 1:25.000 atau pada peta dengan skala yang lebih besar. Umumnya garis batas itu masih berstatus indikatif (perkiraan).

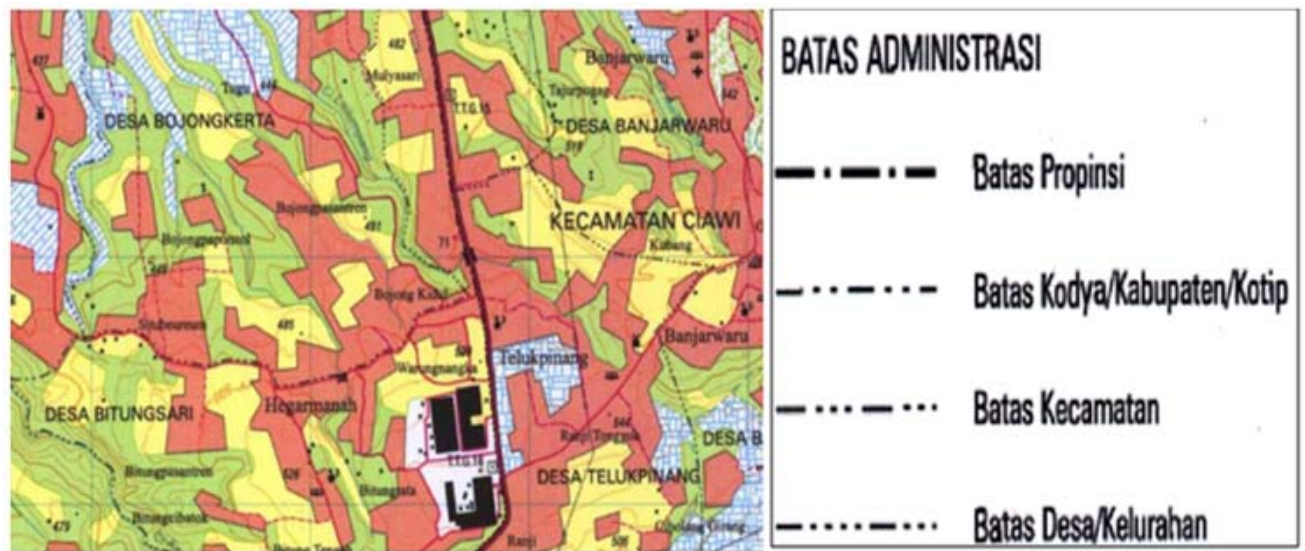

Sumber: Peta RBI Skala 1:25.000, Bakosurtanal.

Gambar 3.

Batas wilayah desa indikatif dan simbol garis batas wilayah

Gambar 3 memperlihatkan garis batas indikatif antara desa Bitungsari (Kabupaten Bogor) dan desa Bojongkerta (Kota Bogor) Jawa Barat di atas peta RBI skala 1 : 25.000. Garis batas ini juga merupakan garis batas Kabupaten Bogor dan Kota Bogor. Walaupun garis batas tersebut masih berstatus indikatif, fakta di lapangan menunjukkan bahwa sebagian garis batas itu berupa jalan raya, dan masyarakat sudah mengetahui bahwa jalan raya tersebut sebagai batas wilayah administrasi seperti terlihat pada Gambar 4. 


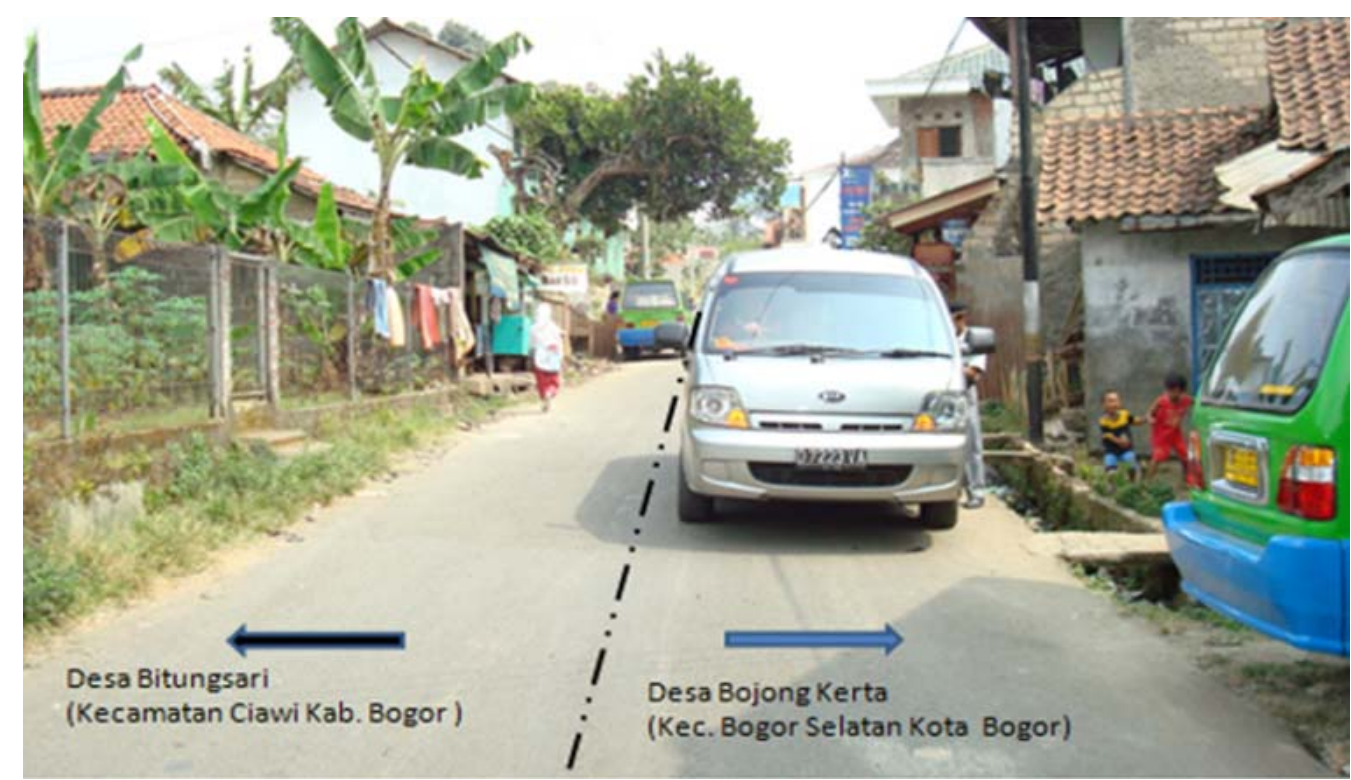

Foto: Asadi, 2012.

Gambar 4.

Median jalan sebagai garis batas wilayah desa

Berdasarkan hasil wawancara dengan penduduk setempat, membenarkan bahwa jalan raya tersebut merupakan garis batas antara desa sebagaimana telah disebutkan. Karena garis batas ini merupakan garis batas kabupaten/kota maka dengan sendirinya juga merangkap sebagai garis batas kecamatan dan garis batas desa.UU Nomor 4 tahun 2011 juga mengamanatkan apabila peta RBI sudah dilengkapi dengan garis batas wilayah definitif, garis batas tersebut harus digambar dengan simbol dan warna yang berbeda dari gambar dan simbol yang saat ini dipakai oleh peta RBI.

Garis batas yang tergambar di atas peta tentu sudah mempunyai posisi dengan nilai koordinat dalam sistem referensi sebagaimana sistem koodinat yang diacu oleh peta dimaksud. Dari data posisi garis batas itu dapat dihitung dan ditentukan luas wilayah desa yang cukup memadai sepanjang peta tersebut sudah sesuai dengan skala dan peruntukannya. Hal penting yang perlu digaris bawahi adalah bahwa angka luas yang diperoleh harus mencantumkan metode perhitungan dan data yang digunakan untuk perhitungan luasan tersebut. Jika hanya mencantumkan angka luas tanpa memberikan informasi tambahan, bagaimana cara perhitungan dan data yang digunakan, maka hal ini akan menimbulkan permasalahan dikemudian hari.

\section{Bentuk Tanda Batas Wilayah}

Tanda batas wilayah di lapangan diwujudkan dalam bentuk tugu atau pilar dengan konstruksi beton bertulang dan dengan ukuran tertentu. Tugu batas desa tersebut dipasang pada garis batas dengan interval jarak tertentu atau sesuai kebutuhan. Setidaknya ada empat tipe tugu batas wilayah, yaitu tipe Amerupakan batas wilayah provinsi, tipe B merupakan batas kabupaten/ kota, tipe C merupakan batas kecamatan dan tipe D ukuran untuk batas desa/kelurahan. Garis batas bisa ditelusuri di lapangan setelah dicapai kesepakatan antara dua desa yang bersangkutan. 
Pemasangan tugu hanya pada garis batas yang layak dan strategis untuk dipasang. Jika tugu batas yang dipasang persis pada garis batas, maka disebut Pilar Batas atau disebut PBU (Pilar Batas Utama). Untuk garis batas seperti median jalan, atau sungai tidaklah mungkin dipasang tugu persis pada garis batas. Pada kondisi seperti ini, dan apabila dianggap layak dan strategis untuk dipasang, maka tugu batas tersebut menjadi pilar acuan batas atau disebut PKB (Pilar Kontrol Batas).
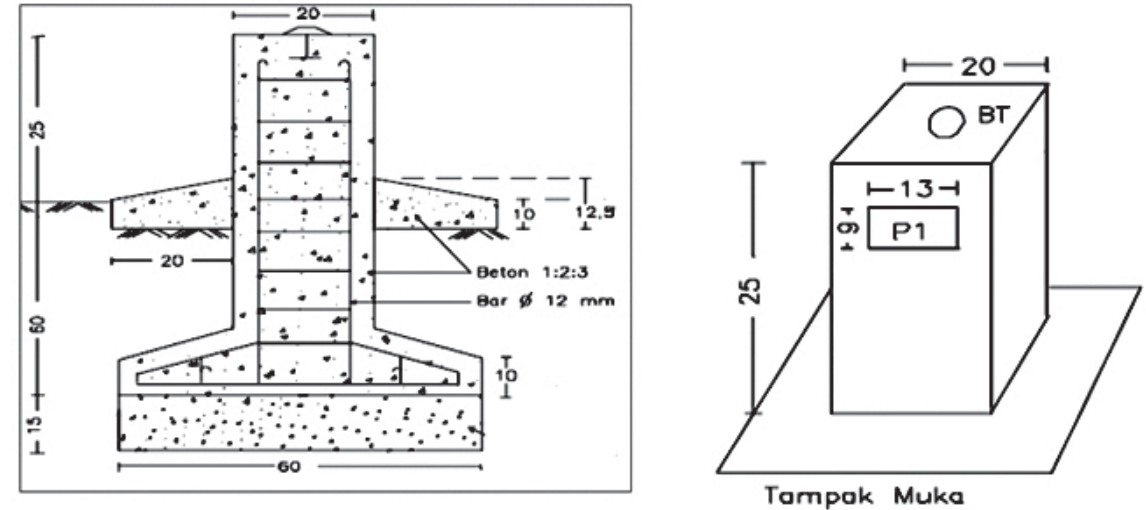

Sumber: Permendagri No.27/2006.

Gambar 5.

Konstruksi Pilar Batas Desa

Pemasangan PKB memberi informasi bahwa di sekitar area tersebut terdapat garis batas wilayah. Secara fisik ukuran PKB sama dengan ukuran PBU. Gambar 5 diatas mengilustrasikan bentuk dan ukuran pilar batas.Pada Gambar 5 ada identitas dan nomor pilar yang dipasang pada bagian atas pilar (BT). Identitas dan nomor pilar terbuat dari bahan kuningan (brass tablet).Pada bagian samping (P1) dipasang identitas desa yang berbatasan. Brass tablet dan identitas desa terlihat pada Gambar 6.

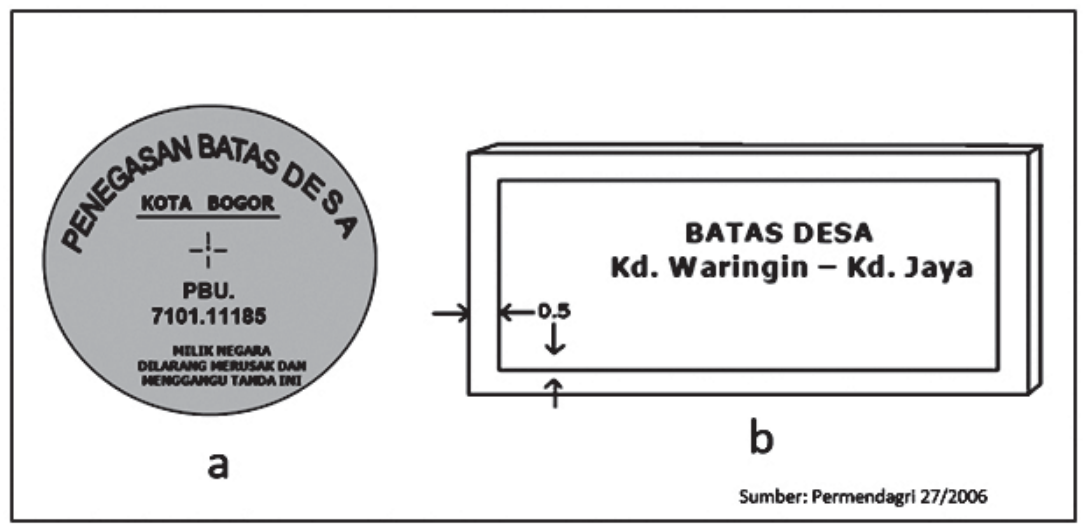

Sumber: Permendagri No.27/2006.

Gambar 6.

Identitas Pilar Batas, (a) berupa brass tablet dipasang di bagian atas pilar dan (b) dipasang pada dinding pilar. 


\section{Peta Wilayah Desa}

Bentuk geometrik wilayah desa sangat bervariasi. Ada yang memanjang ke arah timur barat, utara selatan, ada yang melingkar dan dengan luas yang signifikan berbeda untuk setiap desanya. Sebuah peta wilayah administrasi digambar pada selembar kertas dan tidak nyaman dipandang apabila peta suatu wilayah administarsi digambar pada lebih dari satu lembar kertas. Atas dasar pertimbangan itu, maka penggambaran satu wilayah administrasi dibuat dengan skala peta yang disesuaikan antara luas wilayah dan lembar maksimum ukuran kertas yang ada. Peraturan Menteri Dalam Negeri Nomor 27 Tahun 2006 tentang Penetapan dan Penegasan Batas Desa menyebutkan bahwa peta wilayah desa dibuat pada skala antara 1:10.000 sampai 1:1000. Namun, di beberapa wilayah seperti Kalimantan dan Papua, wilayah desanya relatif lebih luas dibandingkan luas wilayah desa di pulau Jawa.Apabila dibuat dengan skala 1:10.000, beberapa desa di Kalimantan dan Papua tidak bisa digambar dalam satu muka peta akibat keterbatasan ukuran kertas maksimum (Ao). Oleh sebab itu ada pertimbangan lain yang diizinkan untuk membuat peta wilayah desa lebih kecil dari skala yang telah ditentukan.

Data utama untuk pembuatan peta wilayah desa adalah peta RBI. Merujuk kepada UU Nomor 4 Tahun 2011 tentang Informasi Geospasial, setiap peta RBI memuat sembilan unsur, yaitu garis pantai, hipsografi, perairan, nama rupabumi, batas wilayah, transportasi dan utilitas, bangunan dan fasilitas umum, dan penutup lahan. Ke-9 unsur tersebut tentulah sangat diperlukan dalam pembuatan peta wilayah desa. Satu hal yang perlu menjadi perhatian dalam penggunaan peta RBI bahwa batas wilayah (maksudnya garis batas wilayah), sebagaimana telah disinggung, merupakan garis batas indikatif. Garis batas ini wilayah ini tidak bisa dijadikan acuan dalam pembuatan peta desa, kecuali para pihak yang berkepentingan dapat menyetujui garis batas yang ada di peta RBI disepakati untuk dijadikan sebagai garis batas wilayah atau sebagai acuan awal.

Kaidah pemetaan menyebutkan bahwa pembuatan peta tematik (baca peta desa) yang diturunkan dari peta RBI, skalanya tidak boleh lebih besar dari skala peta RBI tersebut. Artinya, jika tersedia peta RBI dengan skala 1:10.000, maka tidak dizinkan membuat peta desa dengan skala lebih besar dari 1:10.000. Semakin besar skala peta maka tingkat kedetilan objek yang tergambar semakin jelas.

\section{Resolusi Spasial Citra Satelit Penginderaan Jauh}

Seperti diketahui, satelit penginderaan jauh menghasilkan citra penginderaan jauh yang dapat dimanfaatkan untuk berbagai kebutuhan informasi tentang objek-objek dipermukaan bumi. Tingkat kedetilan suatu citra satelit penginderaan jauh salah satunya ditentukan dari resolusai spasial. Menurut Projo (2012), pengertian praktis dari resolusi spasial suatu citra satelit penginderaan jauh adalah seberapa ukuran terkecil objek yang dapat dideteksi oleh suatu sistem pencitraan. Semakin kecil ukuran suatu objek yang dapat dideteksi maka dikatakan semakin tinggi tingkat resolusinya. Sebaliknya, semakin besar ukuran objek terkecil yang dapat dideteksi dikatakan semakin rendah tingkat resolusinya. Berdasarkan tingkat resolusi, citra satelit penginderaan jauh dapat dibedakan dalam tiga katagori (Suwargana, 2013), yaitu resolusi tinggi $(0.6 \mathrm{~m}-4.0 \mathrm{~m})$, resolusi menengah $(4.0 \mathrm{~m}-30 \mathrm{~m})$ dan resolusi rendah $(30 \mathrm{~m}$ - >1000 m). Citra satelit resolusi tinggi sering disingkat dengan istilah CSRT dan citra inilah yang dapat digunakan untuk pemetaan skala besar.

Citra yang direkam melalui perekam sensor pada satelit penginderaan jauh masih mengandung kesalahan yang diakibatkan oleh berbagai faktor, antara lain kesalahan geometrik dan faktor kemencengan (Projo, 2012). Faktor kesalahan geometrik tersebut perlu diberikan koreksi 
terlebih dahulu sebelum digunakan.Ada dua tahap untuk memberikan koreksi pada kesalahan geometrik, yaitu kesalahan geometrik yang bersifat sistematik dan pemberian titik kontrol tanah yang teridentifikasi pada citra dan teridentifikasi secara pasti di lapangan. Kesalahan geometrik yang bersifat sistematis biasanya sudah dilakukan oleh penyedia citra. Pemberian titik kontrol atau sering disebut georeferensi adalah proses transformasi untuk mengoreksi sistem koordinat citra menjadi sistem koordinat bumi. Pemberian titik kontrol tanah dilakukan dengan bantuan pengukuran posisi akurat (biasanya dengan pengukuran posisi teliti dengan teknologi GPS) di beberapa area dari citra yang bersangktan. Jumlah sebaran titik kontrol tanah (Ground Control Point, GCP) dibuat dengan sebaran yang merata dengan jumlah titik antara 9 sampai 13 buah (Rudianto, 2011). Bersamaan dengan itu perlu dilakukan juga proses penegakan citra dari faktor kemencengan dan proses ini dikenal dengan istilah ortorektifikasi menggunakan data ketinggian. Faktor lain yang perlu dicatat adalah bahwa luas untuk tutupan awan satu lembar citra (scene) kurang dari 10\% (Projo, 2012).

\section{HASIL DAN PEMBAHASAN}

\section{Ketersediaan Peta RBI Skala Besar}

Seperti telah disampaikan, untuk mendukung pemetaan wilayah desa diperlukan 'bahan baku' berupa peta RBI skala besar, yaitu mulai skala 1:10.000 sampai skala 1:1.000. Sampai akhir tahun 2015, ketersediaan peta RBI skala besar masih sangat sedikit. Untuk peta RBI skala 1:5.000 misalnya, hanya mencapai $0.16 \%$ dan untuk skala $1: 10.000$ hanya mencapai $1.17 \%$ dari kebutuhan yang seharusnya (Tabel-2). Kondisi ini berbanding terbalik dengan jumlah desa saat ini dan tentunya menjadi kendala dalam penyelesaian pembuatan peta wilayah desa.

Di beberapa forum pertemuan, di media massa, saat ini sedang gencar-gencarnya upaya untuk penyelesain penataan batas desa. Pemerintah pun sudah mencanangkan upaya untuk percepatan pemetaan wilayah desa dan pemetaan RDTR (Rencana Detil Tara Ruang). Salah satu alternatif penyediaan 'bahan baku' pembuatan peta tematik skala besar adalah menggunakan citra satelit resolusi tinggi (CSRT) dengan resolusi spasial antara 0.4 s.d. 4 meter. Sebelum digunakan, tentu saja CSRT tersebut perlu terlebih dahulu melalui proses yang disebut ortorektifikasi (tegak) dan georeferensi (sistem koordinat tunggal).

Tabel 1.

Ketersediaan Peta RBI sampai Tahun 2015

\begin{tabular}{|c|c|c|c|c|c|}
\hline Skala & $\begin{array}{c}\text { Cakupan } \\
\text { Nasional }\end{array}$ & $\begin{array}{c}\text { Ketersediaan } \\
\text { s.d. 2014 }\end{array}$ & $\begin{array}{c}\text { Capaian } \\
2015\end{array}$ & $\begin{array}{c}\text { Ketersediaan } \\
\text { s.d. 2015 }\end{array}$ & $\begin{array}{c}\text { Belum } \\
\text { Tersedia }\end{array}$ \\
\hline $1: 1.000$ & - & - & - & - & - \\
\hline $1: 5.000$ & 379.012 & 386 & 204 & 590 & 378.422 \\
\hline $1: 10.000$ & 91.547 & 1074 & - & 1074 & 90.473 \\
\hline $1: 25.000$ & 13.020 & 3894 & - & 3894 & 9.126 \\
\hline $1: 50.000$ & 3.899 & 2834 & 367 & 3201 & 698 \\
\hline $1: 100.000$ & - & 26 & - & 26 & - \\
\hline $1: 250.000$ & 309 & 309 & - & 309 & 0 \\
\hline $1: 500.000$ & 103 & 103 & - & 103 & 0 \\
\hline $1: 1.000 .000$ & 37 & 37 & - & 37 & 0 \\
\hline
\end{tabular}

Sumber BIG, Desember 2015 
Instruksi Presiden RI Nomor 6 Tahun 2012 secara khusus memberikan tugas kepada Badan Informasi Geospasial dan Lembaga Penerbangan dan Antarikasa Nasional untuk menyediadakan, melakukan proses dan menyebarluaskan CSRT atas lisensi Pemerintah Indonesia melalui Infrastruktur Data Spasial Nasional untuk dimanfaatkan bagi kepentingan pembangunan, termasuk untuk pemetaan batas wilayah desa. Adanya Program Nawacita diharapkan upaya-upaya percepatan pengadaan CSRT lebih intensif. Untuk tahun 2016 percepatan penyediaan CSRT akan lebih ditingkatkan dan perjanjian kerjasama dan pakta integritas swakelola antara BIG dan Lapan telah ditandatangani (Warta Geospasial Edisi III/11.1-2 November 2015).

\section{Pemetaan Wilayah Desa Secara Kartometrik}

Sebelum membahas penataan batas wilayah secara kartometrik, perlu terlebih dahulu disampaikan pengertian metode kartometrik dalam penataan batas wilayah. Mengacu kepada Peraturan Mendagri Nomor 76 tahun 2012 tentang Pedoman Penegasan Batas Daerah, metode kartometrik adalah penelusuran/penarikan garis batas pada peta kerja dan pengukuran/ penghitungan posisi titik, jarak serta luas cakupan wilayah dengan menggunakan peta dasar dan peta-peta lain sebagai pelengkap. Penelusuran dan penarikan garis batas pada peta kerja merupakan hal yang bersifat teknis dan dengan ketersediaan teknologi informasi geospasial beserta peta yang sesuai, dapat dilaksanakan dengan mudah dan akurat. Proses penelusuran dan penarikan garis batas pada peta kerja harus melibatkan para pihak terkait, seperti aparat desa, tokoh-tokoh masyarakat desa dan termasuk masyarakat itu sendiri. Mereka lebih mengetahui perkiraan garis batas desa yang akan dilakukan klarifikasi. Jika seluruh segmen garis batas sudah disepakati dan dilakukan penarikan batas secara kartomterik di atas peta kerja, maka perhitungan luas desa bisa diperoleh. Tentunya luas wilayah yang diperoleh berdasarkan penelusuran di atas peta kerja dan cara ini dapat dipertanggungjawabkan karena sudah melalui kesepakatan dan secara teknis sudah mengikuti kaidah-kaidah perhitungan dan pemetaan.

Belum tersedianya peta RBI untuk melakukan proses penatan batas wilayah metode kartometrik bisa dilakukan dengan menggunakan data CSRT yang sudah diolah oleh BIG. Bahkan dari sisi visualisasi permukaan bumi (real world), penggunaan CSRT lebih mudah dimengerti oleh pihak terkait. Pada saat melakukan penelusuran dan penarikan garis batas pada CSRT, masyarakat lebih mengenal dengan baik terhadap objek-objek yang ada dan bisa juga dilakukan cek lapangan. Gambar 7 dan 8 memperlihatkan jalan tanah yang membentang dari arah kiri kanan (arah barat-timur) yang merupakan garis batas wilayah kelurahan Cibinong dan kelurahan Nanggewer Mekar (keduanya dulu masih berstatus desa). Berdasarkan informasi masyarakat yang penulis dapatkan pada saat melaksanakan bimbingan praktikum pelacakan batas pada diklat Penataan Batas Wilayah (2014), bahwa jalan sebagaimana Gambar 8 sudah disepakati sebagai garis batas antara kedua kelurahan tersebut. 


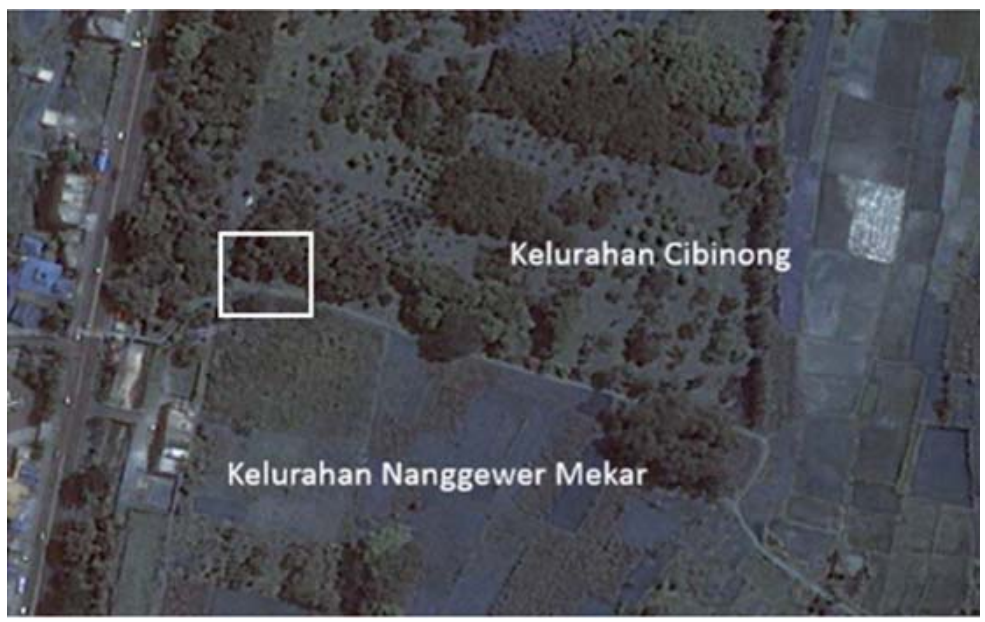

Sumber: BIG, 2014.

Gambar 7.

Citra Ikonos-2 daerah Cibinong Kabupaten Bogor

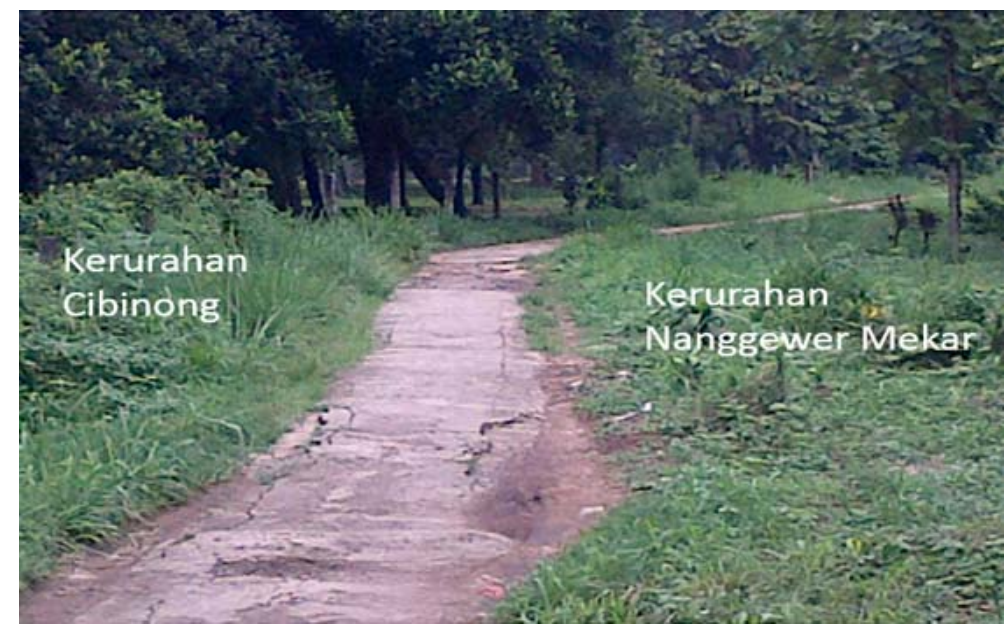

Foto:Asadi, 2016

Gambar 8.

Foto insert dari Gambar 7.

Adanya CSRT yang mempunyai tingkat resolusi spasial antara 50-60 cm, objek-objek detil dari wilayah dimaksud akan terlihat dengan jelas. Aparat desa dan tokoh masyarakat setempat dapat melihat langsung di layar monitor tampilan wilayah desa dan bisa menentukan perkiraan garis batas. Akibatnya proses untuk mencapai kesepakatan para pihak akan lebih cepat. Jika terjadi perbedaan dalam penarikan garis batas, dengan semangat persaudaraan bisa diselesaikan dengan baik. Semangat persaudaraan merupakan kunci utama dalam penyelesaian permasalahan batas dan hal ini perlu disadari oleh semua pihak. Harap dicatat juga bahwa setiap tahapan kegiatan penataan batas yang sudah memperoleh kesepakatan, harus disertai dengan berita acara kesepakatan yang ditandatangani oleh para pihak terkait.

Desa yang sudah memperoleh kesepakatan terhadap seluruh segmen garis batasnya, dapat berlanjut pada pembuatan peta wilayah desa sesuai dengan skala optimal yang bisa dibuat. Apa saja konten yang harus ditampilkan pada sebuah peta wilayah desa, bagaimana simbol- 
simbol dari objek yang tergambar, apakah format peta tersebut dalam bentuk raster ataupun bentuk garis, ini semua harus terlebih dahulu ditentukan dalam Spesifikasi Teknis.

Seperti diketauhui, CSRT tidak mempunyai data ketinggian, hanya ada unsur-unsur planimetrik saja. Akibatnya, jika ingin dibuat peta garis, tidak ada garis kontur, hal ini untuk sementara masih bisa diterima. Kedepan diharapkan data ketinggian untuk pengambaran garis kontur dapat ditambahkan menggunakan data terrain.

Berkaitan dengan skala peta yang akan dibuat, perlu dipertimbangkan penggunaan CSRT yang sesuai, agar didapat skala peta yang optimal. Secara klasik, skala didefinisikan sebagai angka perbandingan antara jarak di atas peta dengan jarak yang bersangkutan di lapangan. Makin besar skala peta, maka tingkat kedetilan objek yang tergambar semakin detil. Tingkat kedetilan suatu citra satelit bisa dilihat dari resolusi spasial yang dimiliki, semakin tinggi resolusi spasial semakin detil objek yang bisa terlihat. Atau, semakin kecil ukuran objek yang dapat direkam, semakin baik resolusi spasialnya.

Kesepadanan antara resolusi spasial suatu citra satelit dengan skala peta telah diformulasi secara matematik oleh Waldo R. Tobler (1987). Pertama, bagi angka penyebut skala peta dengan 1000, kemudian resolusi spasial citra yang sepadan adalah setengah dari hasil pembagian penyebut skala peta tersebut. Sebagai contoh, jika kita inginkan skala peta 1:5.000, maka resolusi spasial citra yang dipersyaratkan untuk mendapatkan skala tersebut adalah $5000: 1000 \times \frac{1}{2}$ meter $=2.5$ meter. Dari formulasi Tobler ini, Laju Gandharum (2011) memberikan hubungan antara skala peta dengan resolusi citra seperti Tabel-3.

Tabel 2.

Hubungan antara skala peta dan resolusi spasial citra

\begin{tabular}{|c|c|c|l|}
\hline Skala Peta & $\begin{array}{c}\text { Terdeteksi } \\
\text { dalam meter }\end{array}$ & $\begin{array}{c}\text { Resolusi } \\
\text { Spasial } \\
\text { Citra }(\mathrm{m})\end{array}$ & $\begin{array}{c}\text { Citra satelit yang sepadan dan } \\
\left.\text { resolusinya dalam meter }{ }^{*}\right)\end{array}$ \\
\hline $1: 1.000$ & 1 & 0.5 & $\begin{array}{l}\text { QuickBird: } \mathrm{p}=0.6 \\
\text { WordView-2: } \mathrm{p}=0.5 \\
\text { GeoEye-1, } \mathrm{p}=0.4\end{array}$ \\
\hline $1: 2.000$ & 2 & 1 & $\begin{array}{l}\text { Ikonos: } \mathrm{p}=1 \\
\text { WordView- } 2: \mathrm{m}=1.8 \\
\text { GeoEye-1, } \mathrm{m}=1.65\end{array}$ \\
\hline $1: 5.000$ & 5 & 2.5 & $\begin{array}{l}\text { QuickBird: } \mathrm{m}=2.4 \text { \& 2.8 } \\
\text { SPOT-5: } \mathrm{p}=2.5-5 \\
\text { Pormosat-2: } \mathrm{p}=2\end{array}$ \\
\hline $1: 10.000$ & 10 & 5 & $\begin{array}{l}\text { SPOT-5: } \mathrm{p}=2.5-5 \\
\text { Ikonos: } \mathrm{m}=4\end{array}$ \\
\hline & & & *) p=pancromatic, $\mathrm{m}=$ multispektral \\
\hline
\end{tabular}

Sumber:Laju Gandharum, 2011

\section{Spesifikasi Teknis Peta Wilayah Desa}

Seperti telah disebutkan sebelumnya, peta wilayah desa dibuat dengan skala antara 1:10.000 sampai 1:1.000. Untuk wilayah desa yang lebih luas bisa dibuat dengan skala lebih kecil dari skala 1:10.000. Apa saja objek yang harus digambarkan pada suatu peta wilayah desa, apa simbol-simbol yang digunakan untuk menggambar jenis-jenis objek, bagaimana 
sistem referensi koordinat yang digunakan dan lain sebagainya yang menyangkut aspek geometrik dan aspek kartografis. Itu semua harus tertuang dengan jelas dan rinci dalam spesifikasi teknis. Dalam Peraturan Mendagri Nomor 27 Tahun 2006 terdapat spesifikasi teknis pemetaaan wilayah desa (Tabel-4), namun hanya menyangkut aspek geometrik, yaitu yang terkait dengan sistem referensi koordinat yang digunakan.

Tabel 3.

Spesifikasi Teknis Pemetaan Wilayah Desa

\begin{tabular}{|c|l|l|}
\hline No. & \multicolumn{1}{|c|}{ Jenis } & \multicolumn{1}{c|}{ Persyaratan } \\
\hline 1 & Datum Horizontal & DGN-95 \\
\hline 2 & Elipsoid Referensi & WGS-84 \\
\hline 3 & Skala Peta & $1: 1.000-1: 10.000$ \\
\hline 4 & Sistem Proyeksi Peta & Transverse Mercator (TM) \\
\hline 5 & Sistem Grid & $\begin{array}{l}\text { Universal Transverse Mercator (UTM) } \\
\text { dengan grid geografis dan metrik }\end{array}$ \\
\hline
\end{tabular}

Sumber: Permendagri No.27/2006

Di dalam Peraturan Kepala BIG Nomor 3 Tahun 2012 tentang Organisasi dan Tata Kerja BIG, pada Pasal 55, Pasal 56 dan Pasal 59 tercantum dengan jelas Pusat Pemetaan Batas Wilayah mempunyai tugas dan fungsi antara lain terkait dengan pembuatan norma pedoman, prosedur, standar dan spesifikasi di bidang pemetaan batas wilayah.

Dalam Peraturan Kepala BIG Nomor 3 Tahun 2016 tentang Spesifikasi Teknis Penyajian Peta Desa terdapat tiga lampiran yang mendeskripsikan lebih detil Spesifikai Teknis, yaitu (1) Penyajian Peta Desa dalam Bentuk Peta Citra, (2) Penyajian Peta Desa dalam Bentuk Peta Sarana dan Prasarana dan (3) Penyajian Peta Desa dalam Bentuk Peta Liputan Lahan.

Dua hal yang perlu dicermati dari Peraturan Kepala BIG Nomor 3 Tahun 2016 di atas, khususnya pada penyajian peta desa dalam bentuk peta citra adalah:(1) Peta desa dapat disajikan dengan ukuran kertas A0 atau A1, tergantung pada luas wilayah desa yang bersangkutan. Tabel 5 dan Tabel 6 memberikan batasan pemberian skala peta dan ukuran wilayah desa. (2) Datum horizontal yang digunakan adalah SRGI 2013. Mengacu pada Peraturan Kepala BIG Nomor 15 Tahun 2013, datum ini sebagai pengganti DGN 95 seperti yang selama ini digunakan (lihat Tabel 3 Spesifikasi Teknis Pemetaan Wilayah Desa di atas). Adapun elipsoid yang digunakan dalam SRGI 2013 adalah WGS-84 dengan parameter sumbu elipsoid, a=6378137.0 meter, $\mathrm{b}=6356752,314245$ meter dan $\mathrm{f}=1 / 298,257223563$.

Tabel 4.

Ketentuan Pemilihan Skala Berdasarkan Ukuran Desa pada Kertas A0

\begin{tabular}{|l|l|l|}
\hline \multicolumn{2}{|c|}{ Ukuran Desa } & \multirow{2}{*}{ Skala Peta Desa } \\
\hline Barat-Timur & Utara-Selatan & \\
\hline$<2,5 \mathrm{Km}$ & $\leq 2,5 \mathrm{Km}$ & $1: 2.500$ \\
\hline $2,5-3,5 \mathrm{Km}$ & $2,5-3,5 \mathrm{Km}$ & $1: 5.000$ \\
\hline $3,5-7 \mathrm{Km}$ & $3,5-7 \mathrm{Km}$ & $1: 10.000$ \\
\hline$>7 \mathrm{Km}$ & $>7 \mathrm{Km}$ & $1: 10.000$ Indeks \\
\hline
\end{tabular}

Sumber: PerKa.BIG No.3/2016 
Tabel 5.

Ketentuan Pemilihan Skala Berdasarkan Ukuran Desa pada Kertas A1

\begin{tabular}{|l|l|l|}
\hline \multicolumn{2}{|c|}{ Ukuran Desa } & \multirow{2}{*}{ Skala Peta Desa } \\
\hline Barat-Timur & Utara-Selatan & \\
\hline$<1.125 \mathrm{Km}$ & $<1.125 \mathrm{Km}$ & $1: 2.500$ \\
\hline $1.125-2.25 \mathrm{Km}$ & $1.125-2.25 \mathrm{Km}$ & $1: 5.000$ \\
\hline $2.25-4.5 \mathrm{Km}$ & $2.25-4.5 \mathrm{Km}$ & $1: 10.000$ \\
\hline$>4.5 \mathrm{Km}$ & $>4.5 \mathrm{Km}$ & $1: 10.000$ Indeks \\
\hline
\end{tabular}

Sumber: PerKa.BIG No.3/2016

\section{Pemekaran dan Penataan Batas Wilayah Desa Pasca UU Nomor 6 Tahun 2014}

Setelah keluarnya UU Nomor 6 Tahun 2014 tentang Desa, pemekaran wilayah desa sedikit terhambat, karena ada beberapa ketentuan dan persyaratan yang harus dipenuhi terlebih dahulu. Salah satu persyaratannya adalah desa tersebut harus sudah mempunyai batas wilayah dalam bentuk peta desa yang telah ditetapkan melalui Peraturan Bupati/Walikota. Melihat kondisi dan ketersediaan peta wilayah desa seperti telah disampaikan terdahulu, agaknya pemekaran wilayah desa untuk sementara waktu tidak terpenuhi.

Persyaratan lain terhadap pemekaran desa yang perlu digarisbawahi adalah kalau pun sudah tersedia garis batas wilayah dan peta desa melalui peraturan bupati/walikota, dan persyaratan lainnya sudah terpenuhi, maka desa pemekaran akan terlebih dahulu menjadi desa persiapan yang memerlukan waktu antara satu sampai tiga tahun untuk menjadi desa definitif setelah melalui evaluasi.

Apabila Pemerintah Daerah (Pemda) ingin segera melakukan penataan batas wilayah desa, sementara ketersediaan CSRT dari BIG belum tersedia, maka pengadaan CSRT dengan alokasi dana APBD tentu bisa dilakukan. Jika keadaan ini terjadi, maka pihak Pemda perlu memperhatikan hal-hal sebagai berikut:

1) Proses ortorektifikasi terhadap CSRT dapat dilakukan sendiri (melibatkan pihak ketiga) dan sebaiknya berkoordinasi dengan BIG.

2) Ketersediaan Jaring Kontrol Geodesi (JKHN) untuk pengikatan GCP sudah tersedia untukseluruh wilayah Indonesia. Data posisi dari JKHNdalam Datum SRGI 2013 dapat diakses di http://srgi.big.go.id/peta/jkg.jsp.

3) Pendistribusian dan pengukuran titik GCP menggunakan metode penentuan posisi dengan teknologi GPS (Global Positioning System) presisi di area CSRT dengan jumlah titik GCP yang memadai agar RMSE hasil perhitungan memenuhi persyaratan, yaitu setengah dari resolusi spasial CSRT yang digunakan.

4) Data DSM (Digital Surface Model) untuk proses ortorektifikasi tersedia di BIG;

5) Untuk proses ortorektifikasi dapat menggunakan aplikasi image processing seperti PCI Geomatic, Erdas Inc., Global Mapper v11, ER Mapper 7.0, dan OrthoWarpER 2.2.

6) Data CSRT yang sudah diortorektifikasi/georeferensi ketitik JKHN menggunakan aplikasi image processing tentunya sudah berada dalam datum SRGI 2013 dan siap untuk digunakan untuk keperluan penataan batas wilayah dengan melibatkan pihak-pihak terkait, termasuk tokoh masyarakat dan masyarakat itu sendiri.

7) Proses pemetaan wilayah desa tetap memperhatikan Peraturan Kepala BIG Nomor 3 Tahun 2016 tentang Spesifikasi Teknis Penyajian Peta Desa.

8) Pengecekakan lapangan (field checking) tetap diperlukan untuk proses identifikasi objekobjek yang belum diketahui dan pemberian nama-nama unsur rupabumi (toponim). 


\section{PENUTUP}

\section{Kesimpulan}

Pemekaran wilayah desa dalam dua dekade terakhir sangat spektakuler. Kondisi ini tentu mempunyai dampak yang baik dimana upaya pemerintah dalam pemekaran desa bertujuan agar kehidupan masyarakat di pedesaan bisa lebih diberdayakan ke arah yang lebih baik. Upaya pemerintah untuk memberikan bantuan dana kepada desa salah satunya didasarkan kepada luas wilayah desa. Agar diketahui luas desa tersebut, tentu sudah tersedia garis batas definitif dan peta wilayah desa. Peta wilayah desa, sebagaimana diatur dalam Peraturan Mendagri Nomor 27 Tahun 2006, dibuat pada skala besar. Pada kenyataannya peta desa sebagaimana yang diharapkan Permendagri tersebut belum terujud. Setidaknya ada dua alasan kendala yang dihadapi, yaitu ketersediaan peta rupabumi skala besar dan pada proses pemekaran wilayah umumnya belum memperhatikan aspek-aspek geodesi.

Ketersediaan Peta RBI skala besar diakui belum tersedia sehingga tidak bisa mengakomodir pembuatan peta wilayah desa. Namun demikian, upaya untuk percepatan pemetaan desa sudah disadari dan langkah-langkah kearah pembuatan peta desa sudah terlihat. Sebagai alternatif, Badan Informasi Geospasial (BIG) dan Lembaga Penerbangan dan Antariksa Nasional (Lapan) telah menyediakan 'bahan baku' pembuatan peta wilayah desa dengan cara penyiapan CSRT. Ketersediaan CSRT tentunya perlu ditindaklanjuti dengan proses ortorektifikasi dan penyediaan titik kontrol tanah (GCP) yang cukup dengan sebaran titik GCP yang memenuhi kualitas ketelitian geometrik dengan nilai Root Mean Square Error (RMSE) maksimum, yaitu setengah dari resolusi spasial dari citra yang digunakan. Sebagai gambaran untuk melihat apakah hasil ortorektifikasi suatu CSRT memenuhi toleransi ketelitian geometrik adalah apabila resolusi spasial suatu CSRT 0.6 meter, maka RMSE maksimm adalah $0.3 \mathrm{~m}$. Ini bisa tercapai jika titik-titik GCP tersebar dengan jumlah antara 9-13 buah dan pengukuran GCP menggunakan teknologi GPS geodetik metode statik.

Deliniasi garis batas secara kartometrik dari CSRT yang sudah melalui proses ortorektifikasi, diharapkan bisa dilakukan untuk mempercepat proses mencapai kesepakatan. Setiap tahap kesepakatan perlu dibuktikan dengan pembuatan berita acara kesepakatan antara pihak terkait. Penyediaan CSRT tetap berlangsung sampai terpenuhinya kebutuhan secara nasional. Sayangnya, peta desa yang diproses melalui CSRT hanya menampilkan bentuk dua dimensi tanpa garis kontur. Terbitnya Peraturan Kepala BIG Nomor 3 Tahun 2016 tentang Spesifikasi Teknis Penyajian Peta Desa memberikan jalan terwujudnya sebuah peta wilayah desa.

Satu hal yang perlu menjadi perhatian adalah dalam penggunaan datum untuk pembuatan peta desa. Antara Peraturan Kepala BIG Nomor 3 Tahun 2016 dan Permendagri Nomor 27 Tahun 2006, terdapat penggunaan datum yang berbeda. Pada Peraturan Kepala BIG Nomor 3 tahun 2016 disebutkan bahwa penggunaan datum adalah SRGI 2013 dimana peraturan ini mengacu kepada Peraturan Kepala BIG Nomor 15 Tahun 2013 tentang Sistem Referensi Geospasial Indonesi 2013 yang pada intinya mengubah penggunaan datum DGN-95 menjadi SRGI 2013. Perubahan datum ini berlaku untuk segala aktifitas pengelolaan data geospasial di seluruh Indonesia.

Dalam proses penataan batas wilayah desa, peran serta masyarakat, tokoh masyarakat dan aparatur desa bersangkutan sangat startegis. Mereka harus dilibatkan sejak awal dalam penyelesaian permasalahan batas wilayah desa. Disamping itu, hal mendasar yang perlu disadari oleh semua pihak yang terlibat dalam penataan batas wilayah desa adalah bahwa dalam penyelesaian permasalahan batas merupakan persoalan kita bersama yang dilandasi semangat persaudaraan, bukan menonjolkan ego masing-masing pihak. 


\section{Rekomendasi}

1) Pemerintah Kabupaten/Kota c.q. Badan Pemberdayaan Masyarakat dan Pemerintahan Desa atau Bagian Tata Pemerintahan:

a. memberikan kesempatan kepada beberapa staf yang punya potensi untuk mempelajari hal-hal yang berkaitan dengan pengelolaan data geospasial dan citra satelit resolusi tinggi.

b. mencari tahu dan berkoordinasi dengan BIG terhadap keberadaan data citra satelit resolusi tinggi wilayahnya untuk dijadikan 'bahan baku' dalam penataan batas dan pemetaan wilayah desa.

c. perlu memberikan sosialisasi dan pemahaman kepada masyarakat tentang penanganan penataan batas wilayah desa

2) Terbitnya Peraturan Kepala BIG Nomor 3 Tahun 2016 tentang Spesifikasi Teknis Penyajian Peta Desa perlu ditindaklanjuti oleh Pemerintah Daerah untuk percepatan pembuatan peta wilayah desa.

3) Adanya perubahan datum dari DGN-95 ke SRGI 2013 sebagaimana tertuang dalam Peraturan Kepala BIG Nomor 15 Tahun 2013 dan diimplementasikan pada Peraturan Kepala BIG Nomor 3 Tahun 2016, khusunya terkait dengan skala peta desa, maka Peraturan Menteri Dalam Negeri Nomor 27 Tahun 2006 perlu dilakukan revisi.

4) Dalam pembuatan peta wilayah desa dari data CSRT secara kartometrik, konten utama apa saja yang perlu disajikan sudah dideskripsikan dalam Peraturan Kepala BIG Nomor 3 Tahun 2016. Namun, ada satu hal penting yang belum dicantumkan dalam peraturan tersebut, yaitu luas area desa. Disarankan agar setiap peta wilayah desa memuat luas desa dan bagaimana teknik perhitungan serta ketelitian dari luas tersebut.

5) Ketersediaan sumberdaya manusia (SDM) dan sumberdaya peralatan pengelolaan data spasial di tingkat desa untuk penataan batas wilayah desa agaknya perlu menjadi perhatian semua pihak.

6) Penegasan batas wilayah desa dengan pemasangan pilar batas seperti diamanatkan dalam Peraturan Menteri Dalam Negeri Nomor 27 Tahun 2006 bisa diminimalkan karena sudah dapat diwakili dalam proses deliniasi garis batas secara kartometrik.

7) Pemasangan pilar batas hanya dibuat pada lokasi yang dianggap pantas untuk dipasang.

\section{DAFTAR PUSTAKA}

Alaska Dispatch News, http://www.adn.com/article/ July 27, 2014. Diakses 20 Pebruari 2016.

Amhar, F. (2001). Kualitas Data, Akurasi dan Skala Peta. Cibinong: Bakosurtanal, Publikasi Terbatas.

Badan Informasi Geospasial. (2015). Warta Geospasial Edisi III/11.1-2 November 2015 Cibinong.

Bakosurtanal. (2009).Spesifikasi Teknis Peta Wilayah Daerah Otonom Kota Skala 1:50.000, Cibinong.

Danoedoro, P. (2012). Pengantar Penginderaan Jauh Digital. Yogyakarta: C.V Andi Offset.

Direktorat Pemberdayaan Masyarakat dan Desa. (2007). Naskah Akademik RUU tentang Desa. Jakarta.

Gandharum, L. (2011, 01 07). Kesepadanan Skala Peta dan Resolusi-Spasial Citra. Diambil dari https://lajugandharum. Diakses tanggal 28 Pebruari 2016. 
Instruksi Presiden Nomor 6 Tahun 2012 tentang Penyediaan, Penggunaan, Pengendalian Kualitas, Pengolahan Dan Distribusi Data Satelit Penginderaan Jauh Resolusi Tinggi

Joyosumarto, S., dkk. (2013). Akselerasi Penegasan Batas Daerah Di Indonesia Dengan Metode Kartometrik. FIT Ikatan Surveyor Indonesia, Yogyakarta.

Nadeak, Hasoloan, dkk.(2015). Batas Wilayah Desa Pasca Berlakunya UU Nomor 6 Tahun 2014 tentang Desa. Jurnal Bina Praja Volume 7 Nomor 3, pp. 239-250 Balitbang Kemendagri.

Noorlaila, Taufik M., 2011.Kajian Ketelitian Planimetrik Citra Resolusi Tinggi pada Google Earth untuk Pembuatan Peta Dasar Skala 1:1.000 Kecamatan Banjar Timur Kota Banjarmasin. Geoid Jurnal Volume 7 No.1, pp. 052-057. Institut Teknologi Sepuluh November.

Prasetyanto, Eko. (2015). Kebijakan Pemerintah Dalam Penetapan dan Penegasan Batas Desa. Direktorat PMDN-Kementerian Dalam Negeri. Publikasi Terbatas.

http://m.republika.co.id/nasional/politik/15/12/10. Edisi 10 Desember 2015. Diakses 20 Pebruari 2016.

Peraturan Menteri Dalam Negeri Nomor 27 Tahun 2006 tentang Penetapan dan Penegasan Batas Desa.

Peraturan Menteri Dalam Negeri Nomor 76 Tahun 2012 tentang Pedoman Penegasan Batas Daerah.

Peraturan Kepala BIG Nomor 15 Tahun 2015 tentang Sistem Referensi Geospasial Indonesia 2013, Badan Informasi Geospasial, Cibinong.

Peraturan Kepala BIG Nomor 3 Tahun 2016 tentang Spesifikasi Teknis Penyajian Peta Desa, Badan Informasi Geospasial, Cibinong.

Peta RBI Lembar 1209-141 Skala 1:25.000, Edisi I 1999, Bakosurtanal.

Rudianto, B. (2011). Analisis Pengaruh Sebaran Ground Control Point terhadap Ketelitian Objek pada Peta Citra Hasil Ortorektifikasi. Jurnal Rekayasa LPPM Institut Teknologi Nasional Bandung No.1 Volume XV, pp 11-18.

Suwargana, Nana. (2013). Resolusi Spasial, Temporan dan Spektral Pada Citra Satelit Landsat, Spot dan Ikonos. Jurnal Ilmiah Widya Volume 1 Nomor 2, pp. 167-174 LIPI.

Sujamto. (1988).Daerah Istimewa Dalam Negara Kesatuan Republik Indonesia, PT.Bina Aksara, Jakarta.

Tobler, Waldo. 1987. Measuring Spatial Resolution, Proceedings, Land Resources Information Systems Conference, Beijing, pp. 12-16.

UU Nomor 4 Tahun 2011 tentang Informasi Geospasial. 
